\title{
What Kind of Charging Infrastructure do Chevrolet Volts Drivers in the EV Project Use?
}

September 2013

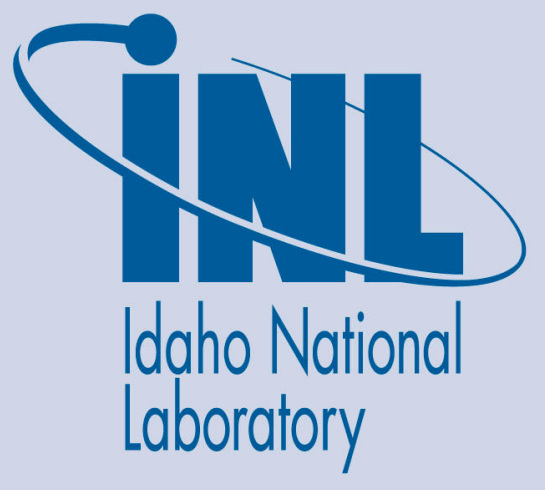

The INL is a U.S. Department of Energy National Laboratory operated by Battelle Energy Alliance 
INL/EXT-13-30053

\section{What Kind of Charging Infrastructure do Chevrolet Volts Drivers in the EV Project Use?}

John G. Smart

September 2013

Idaho National Laboratory
Idaho Falls, Idaho 83415

http://www.inl.gov

Prepared for the

U.S. Department of Energy

Assistant Secretary for Energy Efficiency and Renewable Energy Under DOE Idaho Operations Office

Contract DE-AC07-05ID14517 


\section{VIProject}

\section{What kind of charging infrastructure do Chevrolet Volts drivers in The EV Project use? \\ September, 2013}

\section{Key Conclusions}

- A sample of 1,154 Chevrolet Volt drivers participating in The EV Project performed $86 \%$ of their charging events at home and $14 \%$ away from home over an 8 study month period.

- $20 \%$ of the drivers performed $79 \%$ of the 32,446 awayfrom-home charging events.

- Nearly all home charging was conducted using AC level $2(240 \mathrm{~V})$ charging equipment. About half of all away-from-home charging was conducted using level 2 charging units. The other half of charging away from home was done with vehicles connected to AC level 1 (120 V) charging units or standard 120-volt outlets.

- Vehicles consumed as much energy per charge on average during level 1 away-from home charging events as level 2 away-from-home charging events.

- Drivers which performed $30 \%$ to $60 \%$ of their charging events away from home tended to supplement home charging with away-from-home charging. These drivers averaged $53 \%$ more daily EV miles than the group of vehicles which never charged away from home.

- Drivers which charged away from home for more than $60 \%$ of their charging events tended to replace home charging with away-from-home charging. Their awayfrom-home charging frequency was the same as the home charging frequency of the group of drivers which never charged away from home.

\section{Which vehicles are being studied?}

Over 2,000 private owners of Chevrolet Volts in 18 metropolitan areas across the United States are participating in The EV Project. They agreed to allow project researchers to monitor the usage of their vehicles throughout the project. Data collected between October 1 , 2012 and May 31, 2013 from a sample of 1,154 participating Volts were analyzed to determine how these vehicles are being used. This set of vehicles were driven more than 6 million miles and performed over 223,306 charging events in the 8 month study period.

\section{What kind of charging infrastructure did the vehicles use?}

Volt owners have a number of options for charging their vehicles' batteries. The Chevrolet Volt is capable of charging at both AC level 1 (120 V) and AC level 2 (240 V) charge rates. Each Volt comes with a level 1 cordset that can be plugged into almost any 120 -volt outlet. The Volt can also be charged using any level 2 charging unit equipped with a SAE J1772-compliant connector. Each EV Project participant has such a level 2 charging unit installed at their home.

Charging events in the data from the 1,154 vehicles studied were identified and categorized by location and charge power level. For this study, charge location was classified as either at home, meaning the vehicle owner's primary residence, or away from home. Most charging events were categorized as either level 1 or level 2. The power level of some events could not be determined due to incomplete data. The overall split of the 223,306 charges by location and power level is shown in Figure 1.

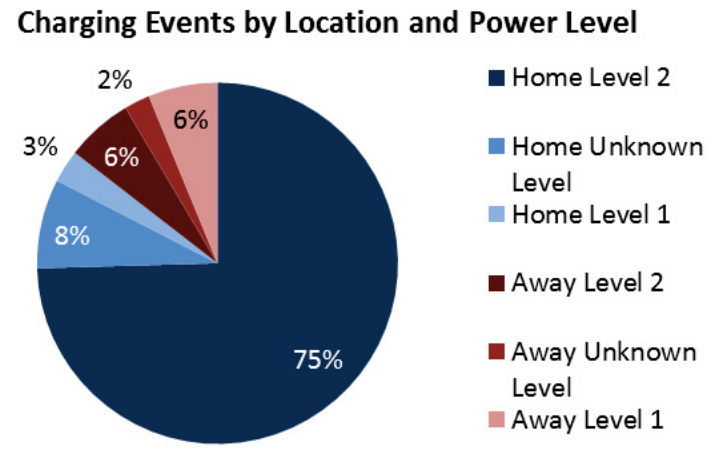

Figure 1: Percent of Volt charging events performed by location and charge power level

The vast majority of Volt charge events (86\%) occurred at home. The vast majority of home charges occurred at the level 2 charge rate, which makes sense because each participant has a level 2 charge unit installed at home. Participants found occasion to charge at home at the level 1 charge rate for $3 \%$ of charge events.

$14 \%$ of charging events occurred away from home. The away-from-home charges with known charge power level were split 50/50 between level 1 and level 2. $2 \%$ of events had an indeterminate charge rate.

Figure 2 shows the amount of charging energy consumed by vehicles during the charging events described in Figure 1. 


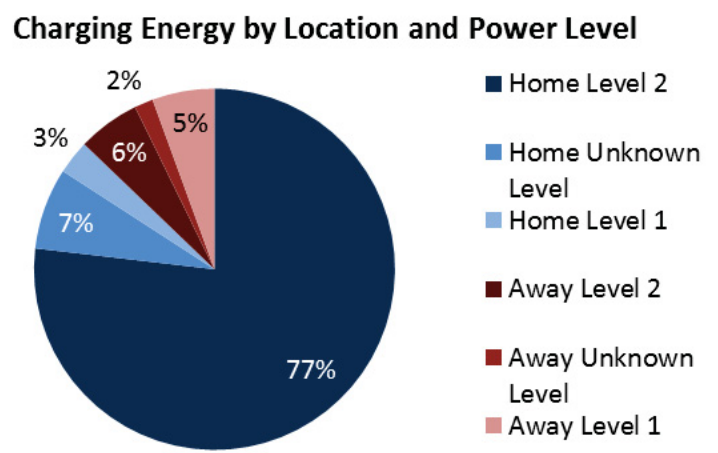

Figure 2: Percent of energy charged by location and charge power level

The proportion of energy charged in each location and charge power level category is very close to the proportion of charging events performed. This means that the energy charged per charging event was nearly equal for level 1 and level 2 charging events, even though level 1 charging occurs half as fast as level 2 . This is particularly significant for away-from-home charging, where charge time is typically expected to be shorter. These results suggest that charging away from home was conducted at locations where the vehicle was parked for long periods of time. Time spent charging at various locations will be explored in other reports.

\section{How did infrastructure usage vary from vehicle to vehicle?}

To understand drivers' usage of away-from-home charging infrastructure, data was analyzed on a per-vehicle basis. First, the relative contribution of away-from-home charging events from each vehicle was calculated to find that $20 \%$ of drivers performed $79 \%$ of away-from-home charging events.

Vehicles were then grouped based on how much awayfrom-home charging they performed relative to home charging. The percent of vehicles in each group is plotted in Figure 7.

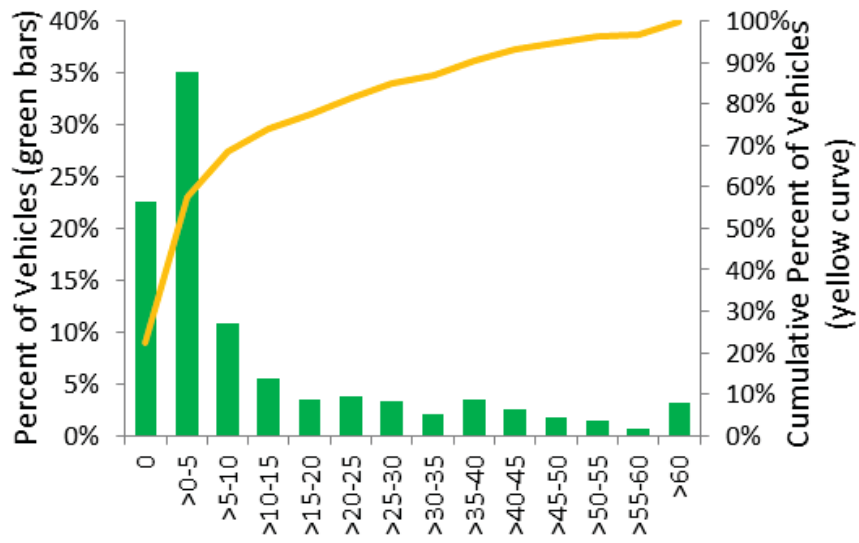

Percent of Charges Away From Home

Figure 7: Distribution of the percent of charges performed away from home by each vehicle

$57 \%$ of the vehicles studied had $5 \%$ or less of their charging away from their home locations. Nearly a quarter of vehicles had no away charges. On the other hand, some vehicles did a majority of their charging away from home, and a few charged away from home $100 \%$ of the time.

Away-from-home charging can be either level 1 or level 2, so looking at the breakdown of away charges by power level is important to further understand drivers' charging habits. Figure 8 shows the percent of charges at each power level for the vehicle groups from Figure 7 .

away Level 2 away Unknown Level $\square$ Away Level 1

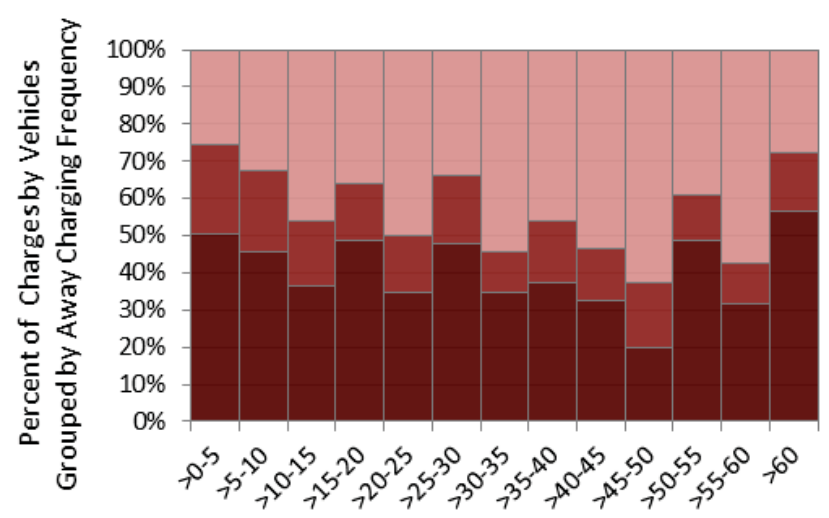

Percent of Charges Away From Home

Figure 8: Occurrence of level 1 and level 2 charging for groups of vehicles with different amounts of away-fromhome charging

Away-from-home charging was split roughly in half between level 1 and level 2 . While it is difficult to quantify exactly due to the number of events with indeterminate power level, it appears that drivers which performed a third 
to half of their charging away from home slightly favored level 1 charging. However, the sample size of each of these groups is relatively small, as shown in Figure 7, so this result may be skewed by atypical charging habits of just a few vehicles in these groups.

\section{Did away-from-home charging enable increased driving in EV mode?}

The vehicles grouped by the percent of charges away from home were analyzed to identify any differences in overall charging behavior and driving behavior. Several metrics were calculated for each group - now consolidated into four groups. These metrics are presented in Table 1.

Table 1: Driving and charging metrics of vehicles grouped by the percent of charges performed away from home

\begin{tabular}{|c|c|c|c|c|}
\hline $\begin{array}{c}\% \text { of Charging } \\
\text { Away from Home: }\end{array}$ & $0 \%$ & $\begin{array}{l}>0- \\
30 \%\end{array}$ & $\begin{array}{l}>30- \\
60 \%\end{array}$ & $>60 \%$ \\
\hline $\begin{array}{l}\text { Vehicles } \\
\text { (\% of total) }\end{array}$ & $\begin{array}{c}259 \\
(22 \%)\end{array}$ & $\begin{array}{c}719 \\
(62 \%)\end{array}$ & $\begin{array}{c}140 \\
(12 \%)\end{array}$ & $\begin{array}{c}36 \\
(3 \%)\end{array}$ \\
\hline $\begin{array}{l}\text { Percent of All away- } \\
\text { from-home } \\
\text { Charging Events }\end{array}$ & -- & $35 \%$ & $47 \%$ & $18 \%$ \\
\hline $\begin{array}{l}\text { Home Charges } \\
\text { Per Day }\end{array}$ & 1.2 & 1.3 & 1.1 & 0.3 \\
\hline $\begin{array}{l}\text { Away-from-home } \\
\text { Charges Per Day }\end{array}$ & -- & 0.1 & 0.8 & 1.2 \\
\hline $\begin{array}{l}\text { Home SOC } \\
\text { Increase } \\
\text { Per Charge }\end{array}$ & 55.9 & 54.7 & 60.5 & 48.5 \\
\hline $\begin{array}{l}\text { Away-from-home } \\
\text { SOC Increase Per } \\
\text { Charge }\end{array}$ & -- & 45.3 & 48.3 & 52.7 \\
\hline $\begin{array}{c}\text { Average Miles Per } \\
\text { Day Driven }\end{array}$ & 34.6 & 39.2 & 50.9 & 38.4 \\
\hline $\begin{array}{l}\text { Percent of Miles } \\
\text { Driven in EV Mode }\end{array}$ & $72 \%$ & $73 \%$ & $75 \%$ & $73 \%$ \\
\hline $\begin{array}{l}\text { Average EV Miles } \\
\text { Per Day Driven }\end{array}$ & 25.0 & 28.4 & 38.3 & 28.0 \\
\hline
\end{tabular}

Vehicles in the three groups with less than $60 \%$ of charges away from home charged at home with similar frequency and duration -1.1 to 1.3 home charges per day with over $50 \%$ increase in SOC per charge, on average. Drivers performing $30 \%$ to $60 \%$ of events away from home supplemented home charging with an average of nearly 1 away-from-home charge per day, which increased their vehicle's SOC an average of nearly $50 \%$ per charge. This additional charging energy allowed these vehicles to be driven an average of 38.3 miles in EV mode each day $53 \%$ farther than vehicles which never charged away from home. (Note that average daily distance driven in EV mode is not the same as the EV mode range of the vehicle. The daily EV-miles metric includes all days driven, including when the vehicle is driven less than the EV range of the vehicle.)

The drivers that charged away from home more than $60 \%$ of the time had the opposite charging behavior of the other groups. They supplemented frequent away-from-home charging with the occasional home charge. These drivers achieved similar EV miles per day as drivers who charged mostly at home.

\section{About The EV Project}

The EV Project is the largest electric vehicle infrastructure demonstration project in the world; designed and managed by ECOtality North America (ECOtality), with a budget of over $\$ 230$ million USD, equally funded by the United States (U.S.) Department of Energy (DOE) through the American Recovery and Reinvestment Act and ECOtality and its partners. The EV Project will deploy and study approximately 13,000 AC Level 2 EVSE charging stations for residential and commercial use, as well as 200 dual-port DC Fast Chargers in conjunction with the usage data from 8,000 Nissan LEAF ${ }^{\mathrm{TM}}$ and Chevrolet Volts. This project will collect and analyze data, and publish lessons learned on vehicle and EVSE use, and driver behavior. This material is based upon work supported by the DOE under Award Number DE-E0002194.

\section{Company Profiles}

ECOtality, Inc. (NASDAQ: ECTY), headquartered in San Francisco, California, is a leader in clean electric transportation and storage technologies. Its subsidiary, Electric Transportation Engineering Corporation (eTec) dba ECOtality North America (ECOtality), is a leading installer and provider of charging infrastructure for PEVs. ECOtality has been involved in PEV initiatives since 1989 in North America and is currently working with major automotive manufacturers, utilities, the U.S. DOE, state and municipal governments, and international research institutes to implement and expand the presence of this technology for a greener future.

\section{blink}

BLINK $^{\mathrm{TM}}$, BLINK LINK ${ }^{\mathrm{TM}}$, EV MICRO-CLIMATE ${ }^{\mathrm{TM}}$ and the BLINK $^{\mathrm{TM}}$ logo are all trademarks of ECOtality, Inc.

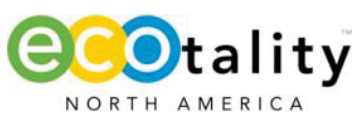

Electric Transportation Engineering Corporation dba ECOtality North America

430 S. $2^{\text {nd }}$ Avenue, Phoenix, Arizona 85003-2418

(602) 716-9576 
Idaho National Laboratory (INL) is one of the U.S.

Department of Energy's (DOE) 10 multi-program national laboratories. The laboratory performs work in each of

DOE's strategic goal areas: energy, national security, science, and the environment. INL is the nation's leading center for nuclear energy research and development. Dayto-day management and operation of the laboratory is the responsibility of Battelle Energy Alliance.

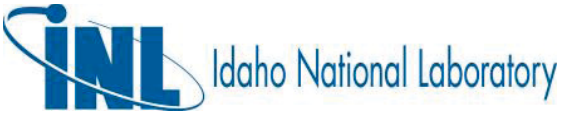

Idaho National Laboratory

2525 North Fremont Avenue

PO Box 1625

Idaho Falls, ID 83415

For more information, visit www.theevproject.com

(c)2013 by Electric Transportation Engineering Corporation. All rights reserved.

No part of the contents of this document may be reproduced or transmitted in any form or by any means without the express written permission of Electric Transportation Engineering

Corporation and the U.S. Department of Energy. 